\title{
World Citizens in Henry $V$ and The Merry Wives of Windsor
}

Ton Hoenselaars

\section{(2) OpenEdition}

\section{Journals}

Electronic version

URL: http://journals.openedition.org/shakespeare/1275

DOI: 10.4000/shakespeare.1275

ISSN: 2271-6424

\section{Publisher}

Société Française Shakespeare

Printed version

Date of publication: 1 November 1994

Number of pages: 115-128

\section{Electronic reference}

Ton Hoenselaars, "World Citizens in Henry V and The Merry Wives of Windsor ", Actes des congrès de la Société française Shakespeare [Online], 12 | 1994, Online since 01 January 2007, connection on 02 May 2019. URL : http://journals.openedition.org/shakespeare/1275; DOI : 10.4000/shakespeare.1275 
COSMOPOLITISME ET INSULARITÉ 


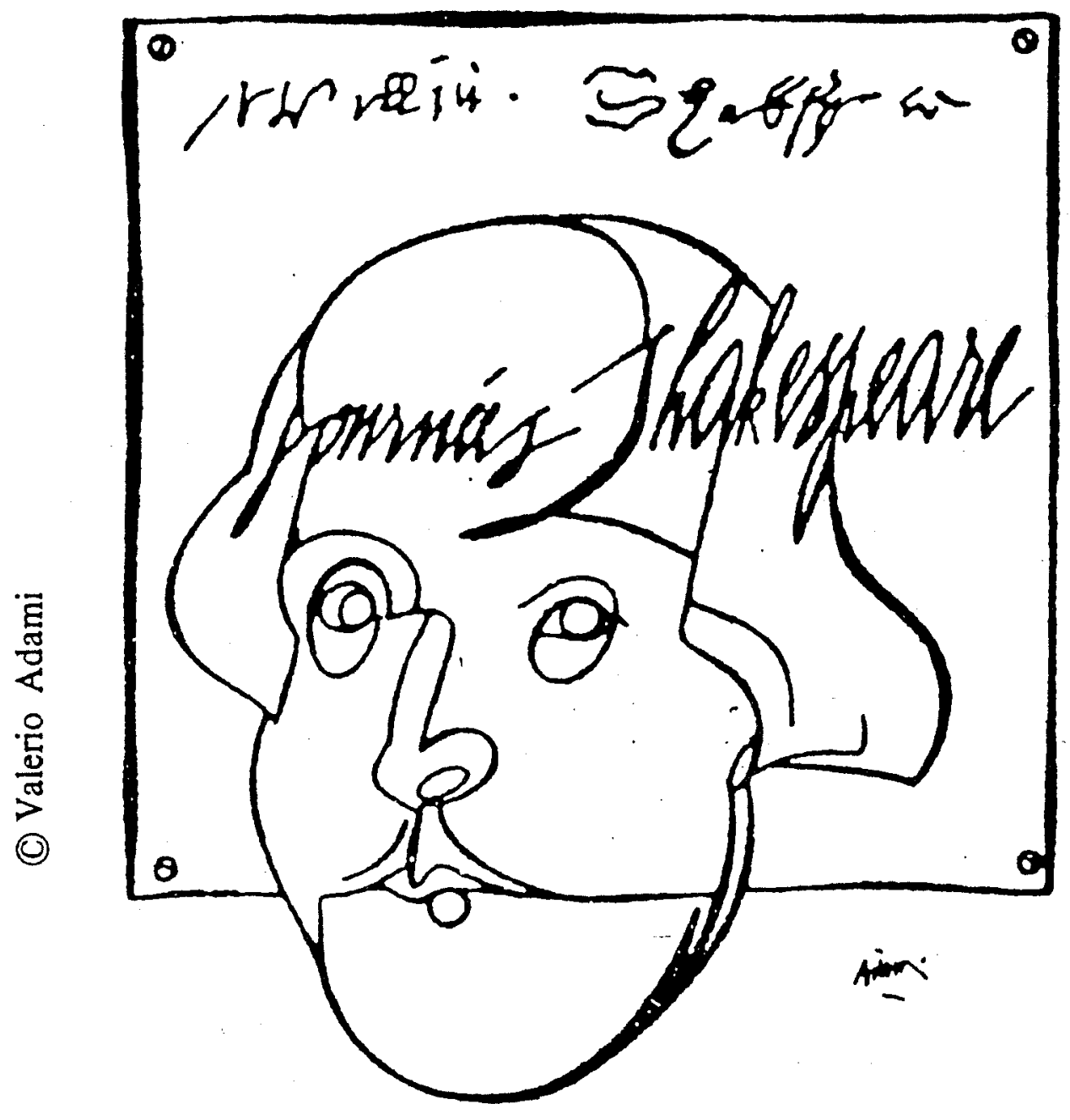

Affiche de Valerio Adami, spécialement conçue pour les journées Shakespeare 1979 


\section{SHAKESPEARE}

COSMOPOLITISME ET INSULARITÉ

Société Française Shakespeare

Actes du Congrès 1993

sous la direction

de

M. T. JONES-DAVIES

Ouvrage publié avec le soutien de

BARCLAYS

BARCLAYS BANK S.A

PARIS

LES BELLES LETTRES

1994 
Tous droits de traduction, de reproduction et d'adaptation réservés pour tous les pays.

(C) 1994 Société d'édition Les Belles Lettres, 95 bd Raspail 75006 Paris

ISBN 2.251.69122-7 


\section{World Citizens in Henry $V$ and The Merry Wives of Windsor}

The critic studying the notions of cosmopolitanism and insularity in Henry $V$ and The Merry Wives of Windsor is, from the very outset, in danger of committing an act of distortion or misrepresentation. The most obvious reason is that the concepts by which such an investigation is to be guided were not part of the English language when the plays were written. In 1598 Richard Hakluyt introduced the word "cosmopolite" to refer to a citizen of the "one mysticall citie vniuersall", but cosmopolitanism as an abstract notion divorced from Saint Augustine's idea of the City of God is a nineteenth-century coinage ${ }^{1}$. Something similar applies to the term insularity. In 1611 Randall Cotgrave defined the French word "Insulaire" in particularly dull and obvious terms as "Insular, Iland-like ; of, or belonging to, an Iland", but again, it took until the second half of the eighteenth century for western consciousness to produce the abstract derivation now known as insularity ${ }^{2}$. Naturally, I would be the first to agree that considerations of this kind need not bar new readings of early modern literature. Like the words cosmopolitanism and insularity, humanism, too, is a product of the nineteenth century, but for all our awareness of this fact, it continues to stand both historians and critics in good stead. In this context, it is indeed curious that one of the main representatives of this so-called humanism also happens to be the alleged founder of our modern sense of cosmopolitanism, namely Erasmus. Interesting, too, is that the avid traveller from Rotterdam not only propagated a supranational school of learning; he also on occasion propagated the merits of a retired existence. Towards the end of his life, for example, he wrote to his friend Goclenius from Basle, and complained about the tiresome religious differences in the Swiss capital. Consequently, he expressed a sincere longing to return to his native north in the words: «Oh, if only Brabant were closer ! ${ }^{3}$ Erasmus also advanced the merits of a more explicitly insular life. $\mathrm{He}$ did so in a letter to the Italian humanist Fausto Andrelini, written during his first residence in London in the summer of 
1499. Since I shall have occasion to return to it later, I shall quote the relevant passage in full :

there are in England nymphs of divine appearance, both engaging and agreeable, whom you would certainly prefer to your Muses; and there is, besides, one custom which can never be commended too highly. When you arrive anywhere, you are received with kisses on all sides, and when you take your leave they speed you on your way with kisses. The kisses are renewed when you come back. When guests come to your house, their arrival is pledged with kisses; and when they leave, kisses are shared once again. If you should happen to meet, then kisses are given profusely. In a word, wherever you turn, the world is full of kisses. If you too, Fausto, once tasted the softness and the fragrance of these same kisses, I swear you would yearn to live abroad in England; and not for ten years only, in the manner of Solon, but all your life long. ${ }^{4}$

Erasmus's references to the world traveller and the permanent resident on his chosen island spot, represent an instance of playful speculation on the notions of cosmopolitanism and insularity. Of course, Erasmus's proposition is primarily a jest, so as a jest it must be welcomed. And the fact that the author's cosmopolitan objective prevails, is best evidenced by the Latin in which the original letter was written, the lingua franca of the humanists. Yet, the options contrasted in Erasmus's letter may, as I hope to demonstrate, prove useful for a reading of Shakespeare.

Approaching the plays from the Erasmian perspective alone, however, would leave the problem involving our two key words unresolved. This would indeed be unfortunate, since an evaluation of the terms in post-Renaissance history may yield equally valuable insights. If words may still be considered to signal the speaker's consciousness at a specific point in time, or if, to speak with Ben Jonson, «No glasse renders a mans forme, or likenesse, so true as his speech», then it is highly appropriate that the two terms cosmopolitanism and insularity should have materialized during the eighteenth and nineteenth centuries, during that era in European history when national awareness and the idea of the nation first became consciously bonded to party political programmes in a manner unknown to the early modern period ${ }^{5}$. It was especially in the nineteenth century during which the rather crude and naive, sovereign-oriented patriotism that Kenneth Minogue associates with the Tudor period, was effectively 
transformed into what is now called the nationalism of later centuries ${ }^{6}$. Indeed, that transformation did not take place overnight, and it owed much to the political philosophies developed during the second half of the seventeenth century and, more pervasively, during the eighteenth. Before turning to Henry $V$ and The Merry Wives of Windsor, I shall briefly discuss several views of cosmopolitanism and insularity in the pivotal eighteenth century. It is my aim, subsequently, to bring the Shakespeare plays with their largely implicit attitude on the subject - into focus between those 18th century ideas and the Erasmian versions of insularity and cosmopolitanism.

For these 18th century views, I go to France, and first to Fougeret de Monbron whose travelogue entitled Cosmopolite ou le Citoyen du Monde appeared in 1750. On a first acquaintance, Fougeret de Monbron looks like the classical cosmopolitan. He is the traveller, for example, who describes how, when about to board a ship for England, the French ambassador told him that, of course, he should not forget that in the past England and France had been at war together. Monbron's response was curt : «Je lui répondis [...] que j'étais habitant du monde, et que je guardais une exacte neutralité entre les puissances belligérantes ${ }^{7}$ ». Yet, it is difficult to deny that Monbron is also an odd example. As Julia Kristeva has aptly remarked, he was a world citizen because he despised all nations - «Citoyen du monde par mépris pour tous les pays ${ }^{8}$. Nevertheless, the case of Monbron has wider significance, since the account of his travels marks a watershed in 18th century views on cosmopolitanism. The favourable early 18 th century view that the cosmopolitan was «un homme qui n'a pas de demeure fixe, ou bien un homme qui n'est nulle part étranger» was countered in the Dictionnaire de l'Académie of 1762 by the damning statement that «Le cosmopolite n'est pas un bon citoyen». The key word in both definitions is "citoyen". Whereas in the first definition it is used metaphorically with reference to the "world" at large, it implicitly refers to "country" or "nation" in the latter. A better appreciation of the new meaning of "citoyen" may be arrived at when we realize that the year 1762 witnessed not only the publication of the Dictionnaire de l'Académie, but also of JeanJacques Rousseau's Émile ou de l'éducation with its notoriously complex reassessment of cosmopolitanism against the background of an emergent nationalist sensibility. Among other things, Rousseau challenged the merit of the cosmopolite's journeys to 
the major capitals of Europe. One of his main reasons was the following:

Toutes les capitales se ressemblent, tous les peuples s'y mêlent, toutes les mœurs s'y confondent; ce n'est pas là qu'il faut aller étudier les nations. Paris et Londres ne sont à mes yeux que la même ville. ${ }^{9}$

For Rousseau it was in the provinces that one should study the customs and the character of a nation. Therefore, part of his alternative to the metropolitan cosmopolitanism of Fougeret de Monbron was a rural or arcadian ideal, and for Émile this is crossbred with the virtues of a sedentary existence. Hence, one of the hero's greatest ideals in life is a piece of land, a territory of his own.

Émile's other ideal is a wife. And this ideal, even if apparently common, captures another aspect of the early nationalist response to cosmopolitanism. As Ieme van der Poel has demonstrated, the cosmopolitanism of the early 18th century cannot be divorced from the widely cultivated libertine lifestyle of men like Casanova and Monbron, who conceived of women as stations on the traveller's way, much like the capital cities they frequented ${ }^{10}$. As Monbron put it in his travelogue : «Voilà l'avantage qu'ont les voyageurs ; ils passent d'une liason a l'autre sans s'attacher a personne» (Cosmopolite, 62). Against this background, Émile's choice of a wife must be interpreted as a profound correlative to his arcadian ideal, an ideal which was to nurture the nationalist models drawn up during the revolutionary decade that ended the eighteenth century.

I shall not consider Rousseau's philosophy in greater detail here, his tragic views on the irreconcilability of the concepts "man" and "citizen", or the deft appropriation of these terms by later generations. These have been analysed with great sensitivity by Tzvetan Todorov in Nous et les autres ${ }^{11}$. More interesting for our present purposes are some of the immediate parallels between Erasmus and Rousseau. Whereas Erasmus as an alternative to cosmopolitanism proposed an insular mode of existence among women in England, the ideal advanced by Rousseau's Émile is that of a retired, anti-urban existence, on a piece of land which he can call his own, like his wife. Erasmus and Rousseau thus may be seen to shake hands across a historical divide of some 250 years, 
and their joint views aptly bring into focus Shakespeare's The Merry Wives of Windsor of 1602.

When discussing The Merry Wives of Windsor, the critic always hastens to add that it is Shakespeare's only comedy with a consistently English setting. The Taming of the Shrew has its Induction set in the dramatist's native Cotswolds, but the scene soon shifts to Italy and remains there. Also the Forest of Arden in As You Like It - even if conclusive evidence were to be gained about its whereabouts - is not the setting of the entire comedy. It is beyond doubt that the choice of England as a location for The Merry Wives of Windsor testifies to the dramatist's concern with matters native. However, this is only part of the truth, arrived at by comparing The Merry Wives to Shakespeare's other ventures in the genre of comedy. Another truth emerges when we witness how critics have studied The Merry Wives against the dramatic output of Shakespeare's contemporaries, in an attempt to redefine the play's generic status. Although both the Quarto and Folio versions of the text describe The Merry Wives as a comedy, critics have tried to read it as a brand of city comedy ${ }^{12}$. Of course, the claim that The Merry Wives is in essence a torqued version of city comedy, may also derive ample support from the New Historicists. Indeed, Elizabeth Pittenger's eccentric article on The Merry Wives entitled "Dispatch Quickly: The Mechanical Reproduction of Pages" could be cited to illustrate the astonishing parallels between the politico-economic conditions determining the production of The Merry Wives in London, and what may be defined as some of the play's major themes ${ }^{13}$. The parallels are of a predictably commercial nature, which, for that very reason, makes it very easy to square The Merry Wives with Northward Ho! or with The Alchemist. Truly, the genesis of each literary text is affected by local mechanisms of commerce and control, but that should not of itself lead us to classify The Merry Wives of Windsor as city comedy.

It seems to me that instead of trying to align The Merry Wives with the increasingly popular genre of city comedy, one should come to appreciate its rural concerns as a conscious departure from the metropolitan genre. And when I use the term "rural", I suggest that Shakespeare's preoccupation is not so different from that of Jean-Jacques Rousseau, who was of the opinion that «les Anglais sont plus Anglais en Mercie qu'à Londres», and that «c'est la campagne qui fait le pays, et c'est le 
peuple de la campagne qui fait la nation» (pp. 613 and 615). Like Rousseau, Shakespeare as a writer of English-based comedy is both anti-metropolitan and anti-cosmopolitan. One could indeed argue that the Henry $I V$ diptych has its famous comic tavern scenes with Hal and Falstaff in London. Yet, the reign of saturnalia here is of a deliberately temporary nature, and it is eventually linked with the geographical issue that concerns us here. The end of Falstaff's rule in London is marked by Henry the Fifth's order at Westminster Abbey «Not to come near our person by ten mile»14. This effectively removes the crown prince's boon companion from the City of London to the countryside, where he re-appears in The Merry Wives of Windsor.

With Windsor, then, Shakespeare opts not just for an English setting, but significantly also for a rural English setting. It makes The Merry Wives of Windsor anti-cosmopolitan, and, by its very nature, also insular. Insularity is explicitly referred to during Falstaff's amorous pursuit of the eponymous wives. Does not Mrs Alice Ford express her amazement at her fat non-native suitor with the words: "What tempest, I trow, threw this whale, with so many tuns of oil in his belly, ashore at Windsor ?»15 The nautical metaphor accompanies much of Falstaff's abortive courtship, but what interests me here is that the description of the suitor marks him not only as a geographical Other to Windsor, but also as a metaphoric stranger to the wives' marital ethics. It is not surprising, therefore, that marital principles should also be aired in terms of geography. To Mrs Page and Mrs Ford, the man who tempts them to adultery is "a Herod of Jewry" (2.1.20) as well as a "Flemish drunkard" (2.1.23). A similar discourse also permeates Falstaff's courtship later in the play. When Falstaff remarks that Mrs Ford has «the right arched beauty of the brow that becomes the ship-tire, the tire valiant, or any tire of Venetian admittance», this exiled cosmopolitan trying to be irresistible is told that a "plain kerchief" will do for her head (3.3.50-54). Thus, rural and marital principles merge in a manner that foreshadows Émile's ideal of a wife, and a plot of ground away from the metropolis. And the views of Mrs Page and Mrs Ford are not incidental. A tendency to see the threat to matrimonial integrity in national terms also pervades the discourse of Mr Ford's jealous rage : «I will rather trust a Fleming with my butter, Parson Hugh the Welshman with my cheese, an Irishman with my aqua-vita bottle [...] than my wife with herself» (2.2.290-94). And once his 
faith in his wife has been restored, he turns to Parson Evans the "mountain foreigner" from Wales - with the words : «I will never mistrust my wife again, till thou art able to woo her in good English» (5.5.134-35).

The predominantly insular perspective in The Merry Wives is, of course, continually brought into focus by its cosmopolitan context. Crucial in this respect is the Garter ceremony which brings foreign visitors to Windsor Castle including Doctor Caius and the mysterious German duke. A central role is given to the Host of the Garter Inn. In purely professional terms, he performs an obvious bridge function between the town of Windsor and the rest of the world, but his character also aptly marks the conflict in the play between its insular and cosmopolitan concerns. The Host of the Garter Inn is one of the few Windsor characters to display an awareness of matters beyond the horizon and an interest in them. Whereas Mrs Ford, as we have seen, prefers a «plain kerchief» to the Venetian headgear that Falstaff considers fit for her, the Host explicitly prides himself on Italian skills with the words: «Am I politic? Am I subtle? Am I a Machiavel ?» (3.1.92-93). The irony is that in the course of the play these apparently rhetorical questions gain the status of factual questions to which the answer is negative. Despite his cosmopolitan leanings, the Host also enjoys to gull the strangers to Windsor. In fact, it is precisely with his desire to play the Machiavel that he aborts the duel between Evans and Caius. It is, therefore, highly appropriate that "Gallia and Gaul" (3.1.89) should, in turn, expose him as a xenophobic insular host by inventing the gentlemen to the German duke and ask for three horses. The Host complies with the request since it will be an opportunity - as he puts it - to "sauce" these foreigners (4.3.9), and the rest is history. If the Host is the unmistakable precursor of Ben Jonson's Sir Politic Would-Be with whom he shares his cosmopolitan prowess as well as his insular behaviour patterns - Shakespeare is the forerunner of $J$. Hillis Miller and his epoch-making deconstruction of the term "host" in $1976^{16}$.

The concepts of insularity and cosmopolitanism in the play may, of course, also be measured by the characters' views of language, of their own language and of other variants. When $\mathrm{Mr}$ Ford states that he will never again distrust his wife until the Welshman is «able to woo her in good English», he links his idea of marital integrity with the linguistic standards of the Windsor 
community. The community's self-conscious adherence to its own language is a principal feature of insularity. Here again, JeanJacques Rousseau comes to our aid, not with his Émile, but with his Discours sur l'origine et les fondements de l'inégalité parmi les hommes, where the very origin of language is attributed to island peoples. In a passage that oddly seems to recall the Book of Genesis, Rousseau remarks :

De grandes inondations ou des tremblements de terre environnèrent d'eaux ou de précipices des cantons habités; des révolutions du globe détachèrent et coupèrent en îles des portions du continent. On conçoit qu'entre les hommes ainsi rapprochés et forcés de vivre ensemble, il dut se former un idiome commun plutôt qu'entre ceux qui erraient librement dans les forêts de la terre ferme ${ }^{17}$.

Initially, Rousseau enables one to intuit as insular the familiar principle behind The Merry Wives of Windsor which is to mark those speakers as Other who - like the Frenchman Doctor Caius - abuse «God's patience and the King's English» (1.4.4). Yet, when studying the play more closely, it appears that the shibboleth device as employed in Shakespeare's Windsor is insular in a rather narrower sense. The protection of an English-language standard in the play is not of a national but of a thoroughly regional kind. As I have already said, in the eyes of Mr Ford, the Welsh parson Evans fails the proficiency test. His dialect is considered substandard, and he is therefore allotted a safe place on the Windsor periphery. Ford's views are even shared by Falstaff. In matters of language even this scapegoat is made to side with the intolerant citizens. As Falstaff puts it in the play's final scene, following his ordeal in Windsor Park : «Have I lived to stand at the taunt of one that makes fritters of English?» (5.5.143-44). We are witnessing here not the emergence of a sense of nationhood determined by the natural borders of Albion, but the invention of an imagined community in regional term $\mathrm{s}^{18}$. We are witnessing the pronouncement of that narrow type of linguistic consensus defined in appropriately insular terms by George Puttenham when he claimed that proper English was «the vsuall speach of the Court, and that of London and the shires lying about London within lx. myles, and not much aboue» ${ }^{19}$.

Cosmopolitanism is far to seek in The Merry Wives of Windsor and - by way of a conclusion - its position is perhaps 
best illustrated with reference to the chaotic Latin lesson, during which William Page is interrogated by Parson Evans (4.1). The very plight of young William, who finds himself caught between the parson with his Welsh accent and Mistress Quickly with her bewildering translations of the Latin into her own profane English, symbolizes the highly delicate status of the cosmopolitan spirit at rural Windsor. Here, the language that Erasmus advanced for his school of learning is both drowned by a comic, local substandard dialect, and by another equally provincial voice that reads into the signifiers of the supranational tongue a reference to public women and Ginny's privates. No wonder, indeed, that William's mind eventually goes blank.

I would now like to leave Windsor, and turn to Henry $V$. I realize that within the context of my analysis of cosmopolitanism and insularity in Shakespeare, Henry $V$ may seem an unorthodox choice. And in a number of ways it is. Yet, when studying Henry $V$ in comparison with The Merry Wives of Windsor, a number of parallels emerge that invite us both to complement and modify some of the conclusions already arrived at. In terms of perspective, Henry $V$ and The Merry Wives of Windsor seem to be diametrically opposed. The narrow Windsor scene constitutes a sharp contrast to the combined English and Continental settings of Henry $V$. The Chorus transports the audience explicitly to the beaches of England to see off Henry's grand fleet, and following his Agincourt victory, we are back on the beach to welcome the king home. The audience is taken both to the periphery of the island, as well as beyond it. In a sense, then, "insular" seems hardly the appropriate term to describe the mood of Henry $V$. This seems to be confirmed also by the marriage that ends the play as part of the peace negotiations, namely that between the king of England and the princess of France. It stands in sharp contrast with The Merry Wives where Doctor Caius's marriage plans with Anne Page ultimately prove abortive, and give rise to the Frenchman's battle cry in broken English «by gar, I'll raise all Windsor» (5.5.207-208).

Yet, in another sense, Henry $V$ is, of course, patently insular, much like The Merry Wives of Windsor. There are myriad of instances in Henry $V$, to illustrate this point, particularly where the attitude towards languages and dialects is concerned. For our present purposes, however, I shall limit myself to the king's courtship of Katherine during the peace negotiations at Troyes. 
Much has been written about the encounter, but what interests me here, are the language barrier that separates the two royal characters, and the issue of national customs or mores which these characters raise. In simple terms, the audience witnesses an encounter beween two speakers who do not share the same language. This is not to say, however, that each does not know enough of the other's language to produce a garbled, though intelligible version of it. This explains why each of the parties involved, at one stage or another, tries to formulate the argument in the other's tongue. But there is no doubt that as the courtship progresses, the English language comes to prevail. Notably, it is the same English language which had gradually become the official court language under the historical Henry the Fifth, and which, in the course of the fifteenth century, had become known by the proverbial phrase the King's English, the phrase also employed in Shakespeare's Windsor ${ }^{20}$. Once we recognize that the English language gradually comes to dominate the dialogue between Katherine and her suitor, Henry $V$ proves no less insular than The Merry Wives of Windsor. It is true that Henry allows Katherine to speak her mind in broken English, but after all, the hoped-for marriage is part of the peace negotiations at Troyes. And within Shakespeare's ideology of language, concessions of the kind that Henry makes are warranted to establish peace. Henry the Fifth speaks very much like the Host in The Merry Wives when the Windsorian tries to restore the peace, which is at that point disturbed by Caius and Evans. «Disarm them, and let them question», the Host commands «let them keep their limbs whole, and hack our English» (3.1.71-72).

In all this, one may wonder where Shakespeare's sympathies lay. As the many analyses of the dialectic between the Chorus to Henry $V$ and the actual play have amply demonstrated, Shakespeare's sympathies were not by definition with the eponymous king. Yet, where his own medium was concerned, the English language that is, the dramatist supported the king's strategy, and effectively rallied the popular audience behind him. Pivotal to his tactics is Katherine's language lesson in the fifth scene of Act three. For a proper understanding of the scene, it seems significant to note first of all that it is the only occasion in the entire canon of English Renaissance drama where a foreigner learns, or tries to learn English. In this sense, the scene already marks a distinct movement away from French to English. And although from a modern perspective one might, with a fair 
measure of irony, be tempted to define Katherine's endeavours like those of Doctor Caius, Parson Evans, or young William as cosmopolitan, this would hardly seem to be Shakespeare's point. Crucial in the scene, it appears to me, is that the English audience, or at least the popular component of it, was excluded from the fun. It cannot be sufficiently stressed that the bawdy play of words uttered by princess Katherine may only be understood with a fair proficiency in French. This explains why, to the present day, monolingual English audiences must witness the scene with vertical eyebrows while the informed highbrows - be they bardolatrous or simply francophone - giggle. We may never gain greater certainty about the foreign-language skills of Shakespeare's audiences. Yet one can safely argue that during the language lesson those audience members unversed in French were made to experience, in advance, Henry's distress in the final scene of the play, and would as a consequence gladly have seconded the king's bold assertion of the English language.

The conquest of English over French marks what may be termed a mode of insu!ar expansionism or of expansionist insularity. But significantly, so does the kiss which concludes the courtship, the kiss which symbolically silences Katherine for the rest of the play. Although the kiss involves the use of lips like speech, it is worth noting that it also raises the issue of conflicting national customs. Katherine of Valois may maintain that «Les dames et demoiselles, pour être baisées devant leurs noces, il n'est pas la coutume de France», but King Henry argues back with the words :

O Kate, nice customs curtsy to great kings. Dear Kate, you and I cannot be confined within the weak list of a country's fashion. We are the makers of manners, Kate, and the liberty that follows our places stops the mouth of all find-faults, as I will do yours, for upholding the nice fashion of your country in denying me a kiss ${ }^{21}$.

It is generally assumed that Henry the Fifth advances the royal prerogative with Katherine to establish their own manners. To a certain extent he does. Yet, it is equally important to note that on the present occasion at least he imposes, together with the English language, his own English manners. He imposes on Katherine the same custom of premarital kissing that had in 1499 inspired the copious wording of Erasmus's letter to Andrelini ; and it was still 
an acknowledged English custom in 1621, when Robert Burton in his Anatomy of Melancholy raised it to praise his countrymen and coutrywomen ${ }^{22}$. In the foreign French setting of Henry $V$ then, the Englishman's insularity prevails, both in terms of language and of etiquette.

As I have argued, there is between the defensive regionalism of The Merry Wives of Windsor and the aggressive expansionism of Henry $V$ little space for any cosmopolitan views. If The Merry Wives of Windsor may in various ways be seen to propagate the merits of insularity as a correlative to marital integrity, Henry $V$ illustrates this principle on a larger scale with its final marriage marking even more than just a military or linguistic victory. The question arises to what extent Shakespeare himself supported the views he dramatized. After a long critical struggle with my acknowledged tendency towards bardolatry, I have arrived at the conclusion that, if cosmopolitanism is a virtue - and as a compatriot of Erasmus, and born in the same city as Erasmus, I am inclined to think it is - Shakespeare was not a cosmopolitan dramatist, especially not when matters national or English were at stake. That he should nevertheless be the world's most popular dramatist, can only be explained by the fact that he is universal as they say, universal in the sense that one tends to recognize both in The Merry Wives of Windsor and in Henry $V$ a range of most appealing emotions of a partisan kind. Expressing my views in this manner, I both imply and explicitly mean to say that insularity, patriotism, and also what since the end of the 18th century has become known as nationalism, continue to be many times more popular than cosmopolitanism. And I do not venture into the realm of conjecture when I argue that the two plays I have discussed here - both long available on the market in print, and staged the world over - have unfortunately rehearsed sentiments that Shakespeare may have considered proper for audiences in his own time, but which for obvious reasons we have come to be wary of since.

Ton HOENSELAARS

Université d'Utrecht 


\section{NOTES}

1. The Oxford English Dictionary, second edition, sub "cosmopolite" (1).

2. The Oxford English Dictionary, second edition, sub "insular" (A.1.a).

3. Desiderius Erasmus, Opus epistolarum Des. Erasmi Roterodami, edited by P. S. Allen and H. M. Allen, vol. XI (Oxford, 1947), 337 ["Vtinam Brabantia esset vicinior"].

4. The Correspondence of Erasmus, Letters 1 to $141: 1484$ to 1500 , translated by R. A. B. Mynors and D. F. S. Thomson, and annotated by Wallace K. Ferguson (Toronto, 1974), 193.

5. Ben Jonson, edited by C. H. Herford and P. and E. Simpson, 11 vols. (Oxford, 1925-52), VIII (1947), p. 625, 11. 2033-35.

6. K. R. Minogue, Nationalism (London, 1967), 24.

7. Fougeret de Monbron, Le Cosmopolite ou le Citoyen du Monde suivi de La Capitale des Gaules ou la Nouvelle Babylone, edited by Raymond Trousson (Bordeaux, 1970), 122.

8. Julia Kristeva, Étrangers à nous-mêmes (Paris, 1988), 210.

9. Jean-Jacques Rousseau, Émile ou de l'éducation, edited by Michel Launay (Paris, 1966), 612.

10. Ieme van der Poel, "Liberté, Égalité ... Alterité : Les Etrangers dans une Europe Unie", in National Identity: Symbol and Representation, edited by J. Th. Leerssen and M. Spiering, Yearbook of European Studies, vol. 4 (Amsterdam and Atlanta, Ga., 1991), 193202 (pp. 197-99).

11. Tzvetan Todorov, Nous et les autres: La réflexion française sur la diversité humaine (Paris, 1989), 199-211.

12. See a.o. Alexander Leggatt, Citizen Comedy in the Age of Shakespeare (Toronto, 1973), 146-47 ; Maurice Charney, "Shakespeare and the Others", Shakespeare Quarterly, 30 (1979) 32142; Brian Gibbons, Jacobean City Comedy, second edition (London and New York, 1980), 104-109; G. K. Hunter, "Bourgeois Comedy: Shakespeare and Dekker", in Shakespeare and His Contemporaries: Essays in Comparison, edited by E. A. J. Honigmann, 1-15 (Manchester, 1986), 1-15.

13. Elizabeth Pittenger, "Dispatch Quickly: The Mechanical Reproduction of Pages", in Shakespeare Quarterly, 42 (1991), 389. 408.

14. The Second Part of King Henry IV, edited by A. R. Humphreys, The Arden Edition (London, 1966), 5.5.65.

15. The Merry Wives of Windsor, edited by H. J. Oliver, The Arden Edition (London, 1971), 2.1.61-63. 
16. J. Hillis Miller, "The Critic as Host", in Critical Inquiry, 3 (1988). Reprinted in Modern Criticism and Theory: A Reader, edited by David Lodge (London and New York, 1988), 277-85.

17. Jean-Jacques Rousseau, Euvres Politiques, edited by J. Roussel (Paris : Bordas, 1989), 56.

18. My phrase "imagined community" refers to Benedict Anderson's Imagined Communities : Reflections on the Origin and Spread of Nationalism ([1983] Rev. ed. London and New York, 1991). Of special interest for our present purposes is chapter 3 on "The Origins of National Consciousness" (pp. 37-46).

19. Elizabethan Critical Essays, edited by G. Gregory Smith, 2 vols. (Oxford, 1904), II, 150. See also Richard W. Bailey, Images of English: A Cultural History of the Language (Cambridge, 1992), 1736.

20. On the gradual emergence of the King's English, see John $\mathrm{H}$. Fisher, "A Language Policy for Lancastrian England", in PMLA, 107 (1992), 1168-80.

21. King Henry $V$, edited by Andrew Gurn, The New Cambridge Shakespeare (Cambridge, 1992), 5.2.233-34 and 5.2.243-48 respectively.

22. Robert Burton, The Anatomy of Melancholy, edited by Holbrook Jackson (1932; rpt. London, 1961), iii.265. The English habit of kissing is the subject of an extended discussion in Robert Davenport's The City Nightcap (1624). See Willis J. Monie, A Critical Edition of Robert Davenport's 'The City-Night-Cap' (New York, 1979), I.ii. See also Lawrence Stone, The Family, Sex and Marriage in England, 1500-1800, abridged edition (Harmondsworth, 1979), 325. 